\title{
Improving Student's Communication Skills in Social Science Learning Through a Scientific Approach
}

\author{
Ismail Buhari $^{1}$, Tri Zahra Ningsih ${ }^{2}$ \\ ${ }^{1}$ Widyaiswara BPSDM Provinsi Jambi, Jambi, Indonesia \\ ${ }^{2}$ SMP Negeri 46 Kerinci, Jambi, Indonesia
}

\begin{abstract}
The goal of this study is to see if using a scientific approach might help students enhance their communication abilities in social studies classes. A one-group pretest-posttest research design was adopted in this research. The research participants were students from SMP Negeri 46 Kerinci, with a total population of 95 students and a sample of 30 students from class VIII. The sampling approach used in this research was a random sample technique. Observation sheets and a communication skills assessment were used to collect data. IBM SPSS version 25 software was used to statistically analyze the research data. The findings imply that teaching social studies using a scientific approach has a significant influence on students' communication skills. This is confirmed by the difference in average scores between the pretest and posttest tests. Also suggestive is a t-test significance value of 0.000 or less than 0.05 .
\end{abstract}

KEYWORDS: Communication Skills, Scientific Approach, Social Science Learning

\section{INTRODUCTION}

One of the disciplines taught in schools is social studies, which focuses on the practical elements of learning, studying symptoms, and social issues in society. According to the NCSS (National Council for the Social Studies), the purpose of social studies is to prepare students to make decisions as members of a culturally diverse society, as well as to become citizens with the knowledge needed, values, attitudes, and skills to participate in democratic life on a local, national, and global level (Zahabioun et al., 2013).

Following the aims of social studies, social studies disciplines are eventually beneficial in preparing students to engage actively in society, develop social life skills, communicate, and collaborate on a local, national, and global scale. When seen through the lens of the aims and abilities that must be developed in social studies, social studies may play a critical role in strengthening students' social skills (Indriyani et al., 2021). Setiawan (2017) also states that the purpose of social learning is for students to be able to recognize concepts related to community life and the environment, have the necessary skills in logical and critical thinking, curiosity, inquiry, problem solving, and social skills in socializing, have social and humanitarian commitment and awareness, respect values, communicate, cooperate, and compete in a pluralistic society at local, national and global levels.

Communication skills are one of the abilities that must be cultivated in order to achieve social studies learning objectives. This corresponds to the needs of the twenty-first century. In the twenty-first century, technology advances at a breakneck pace. In this situation, everyone must think critically, creatively, and responsively in order to stay up to date with technological advances (Permanawati et al., 2018). However, other researchers state that not just critical and creative thinking abilities, but also communication and teamwork skills must be developed. Both abilities are crucial in the development of a child's world (Chasanah et al., 2020).

However, most of the problems in social studies learning are the lack of students' communication skills. Students are less proficient in articulating learning outcomes in front of the class through presentations. According to the findings of the initial assessment of students' communication abilities, 37.5 percent of students are proficient at communicating the outcomes of class discussions in front of the class, while 62.5 percent are less skilled. Lack of students' communication skills in social studies learning, as a result of students' lack of confidence in Students' deficient communication skills in social studies learning, as a result of led to a lack of confidence in expressing the discussion's outcomes. This is because the teacher still uses the lecture teaching mode.

Several studies (eg, Marbach-Ad, Seal, \& Sokolove, 2001; Jungst et al., 2003) show that the lecture method is not effective in social studies learning because it allows students to be passive recipients of information (Hansen \& Stephens, 2000), become dependent on 


\section{International Journal of Current Science Research and Review}

ISSN: 2581-8341

Volume 04 Issue 12 December 2021

DOI: 10.47191/ijesrr/V4-i12-14, Impact Factor: 5.825

IJCSRR@ 2021

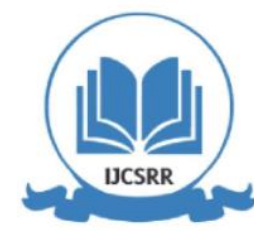

Www.ijcsrr.org

the teacher (Machemer \& Crawford, 2007), and the information acquired as a result of learning is relatively superficial and transient (Moust et al., 2005). In addition, the lack of student communication skills in social studies is also caused by the use of scientific methods in learning that is less than optimal. Learning with a scientific approach can improve conceptual understanding (Syarifuddin, 2018; Tambunan, 2019), increases learning independence, has a significant impact on learning outcomes (Ariawan et al., 2015; Untayana \& Harta, 2016; Wibowo, 2017), has an effective effect on learning achievement, and student learning outcomes. According to various studies, the scientific approach also can help pupils enhance critical thinking abilities, cooperation skills, problem-solving skills, and communication skills (Corrales-Reyes \& Dorta-Contreras, 2018; Yafie et al., 2020, Hernawati et al., 2018). Based on the discussion above, this study intends to describe the effect of utilizing a scientific approach to improve students' communication skills in social studies learning.

\section{RESEARCH METHODS}

This study used a one-group pretest-posttest research design, which comprised a pretest before treatment and a posttest after treatment (Mertens, 2019). The term "one group" refers to the fact that there is no control group in this design. However, this study was done in an 8th grade pretest and posttest group to see if employing a scientific approach may help kids improve their communication skills. The following is a summary of the research methodology:

$$
\mathrm{O} 1 \mathrm{X} \mathrm{O} 2
$$

Figure 1: Research design formula in a single group, pre- and post-testing

From September 2021 to October 2021, this study was done at SMP Negeri 46 Kerinci in Jambi. Students from SMP Negeri 46 Kerinci were the research participants, with a total population of 95 students and a sample of 30 students from class VIII. This study employed a random sample strategy as its sampling method. Random sampling is a sampling strategy in which all people in a population are given the same chance to be chosen as sample members, either individually or collectively. In this study, data was collected using observation sheets and a communication skills assessment. Observation sheets were used to collect information regarding the learning approach used in the classroom. The purpose of the assessment sheet is to assess pupils' communications skills. The assessment sheet has nine indicators that are used to assess students' communication skills using a Likert scale. The scale has five options, with the greatest score indicating that the student is extremely proficient and the lowest indicating that the student is very unskilled. The assessment of students' communication skills was done twice, once for the pretest and once for the posttest. This is done to explore how employing a scientific approach might help students improve their communication skills. To establish if there was an impact of delivering treatment or not, data was analyzed using an independent sample t-test with a significant threshold of 5\%. A pre-requisite exam was conducted on the communication skills data received before the t-test was conducted. Normality and homogeneity tests are two necessary tests. The research data was statistically analyzed using IBM SPSS version 25 software.

\section{RESULT RESEACRH}

The following are the findings of the communication skills assessment utilizing nine assessment indicators:

Table 1. Shows the statistical description of the pretest test data.

\begin{tabular}{|l|l|l|l|l|l|l|}
\hline & $\mathrm{N}$ & Minimum & Maximum & Mean & Std. Deviation & Variance \\
\hline Indikator 1 & 30 & 2 & 3 & 2.10 & .712 & .507 \\
\hline Indikator 2 & 30 & 2 & 3 & 2.33 & .711 & .506 \\
\hline Indikator 3 & 30 & 3 & 3 & 2.33 & .479 & .230 \\
\hline Indikator 4 & 30 & 2 & 4 & 3.07 & .640 & .409 \\
\hline Indikator 5 & 30 & 2 & 4 & 3.13 & .730 & .533 \\
\hline Indikator 6 & 30 & 2 & 3 & 2.27 & .640 & .409 \\
\hline Indikator 7 & 30 & 2 & 3 & 2.33 & .711 & .506 \\
\hline Indikator 8 & 30 & 2 & 3 & 2.93 & .583 & .340 \\
\hline Indikator 9 & 30 & 2 & 3 & 2.80 & .484 & .234 \\
\hline
\end{tabular}




\section{International Journal of Current Science Research and Review}

ISSN: 2581-8341

Volume 04 Issue 12 December 2021

DOI: 10.47191/ijcsrr/V4-i12-14, Impact Factor: 5.825

IJCSRR@ 2021

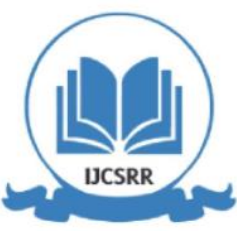

www.ijesrr.org

Based on the data in table 1, The average student is known to have a score of 2 with in category of being less skilled in communicating learning outcomes in front of the class. This means that with the use of a teacher-centered learning approach, students become less skilled in communicating learning outcomes in front of the class. In furthermore, the test results are presented in table 2 to determine whether there's a rise following treatment.

Table 2. Shows the statistical description of the posttest test data.

\begin{tabular}{|l|l|l|l|l|l|l|}
\hline & $\mathrm{N}$ & Minimum & Maximum & Mean & Std. Deviation & Variance \\
\hline Indikator 1 & 30 & 4 & 5 & 4.20 & .407 & .166 \\
\hline Indikator 2 & 30 & 4 & 5 & 4.17 & .379 & .144 \\
\hline Indikator 3 & 30 & 4 & 5 & 4.03 & .183 & .033 \\
\hline Indikator 4 & 30 & 4 & 5 & 4.20 & .407 & .166 \\
\hline Indikator 5 & 30 & 4 & 5 & 4.17 & .379 & .144 \\
\hline Indikator 6 & 30 & 4 & 5 & 4.13 & .346 & .120 \\
\hline Indikator 7 & 30 & 4 & 5 & 4.20 & .407 & .166 \\
\hline Indikator 8 & 30 & 4 & 5 & 4.13 & .346 & .120 \\
\hline Indikator 9 & 30 & 4 & 5 & 4.20 & .407 & .166 \\
\hline
\end{tabular}

Based on the information in table 2, it is determined that the average student has a score of 4-5. This implies that after receiving treatment in the social studies learning process using a scientific approach, students become very adept at communicating learning results in front of the class. It is known that there is a mathematical difference between before and after treatment when using a scientific approach to students' communication skills in social studies learning based on the average score of the posttest test, as shown in figure 2.

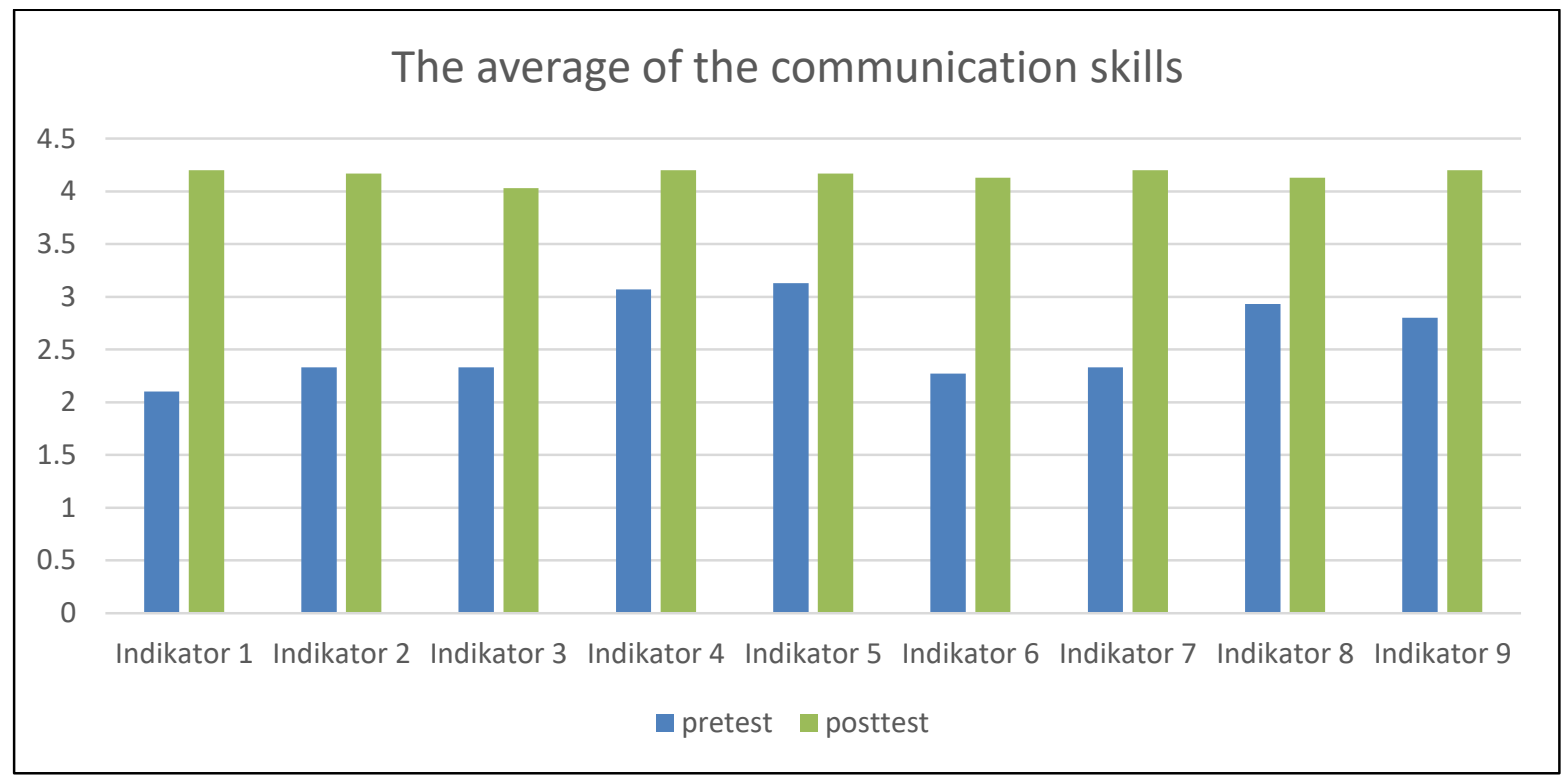

Figure 2. The average of the communication skills exam results of SMP Negeri 46 Kerinci class VIII students

Figure 2 shows that after receiving treatment through a scientific approach, students' communication skills increased. However, to ascertain whether there was a significant effect, a t-test with an independent sample t-test was used to see if there was a significant effect of utilizing a scientific approach on students' communication skills in social studies learning. A precursor test must be performed before the $t$ test, specifically normality and homogeneity tests, to determine whether the data used are normally distributed and homogenous. The Kolmogorov Smirnov test was used to determine normality, and the Levene Statistics test was used to determine homogeneity. The following table shows the results of the normality and homogeneity tests. 


\section{International Journal of Current Science Research and Review}

ISSN: 2581-8341

Volume 04 Issue 12 December 2021

DOI: 10.47191/ijesrr/V4-i12-14, Impact Factor: 5.825

IJCSRR@ 2021

www.ijesrr.org

Table 3. Normality test results

One-Sample Kolmogorov-Smirnov Test

\begin{tabular}{lll} 
& & Unstandardized Residual \\
\hline $\mathrm{N}$ & & 30 \\
\hline Normal Parameters $^{\mathrm{a}, \mathrm{b}}$ & Mean & .0000000 \\
\cline { 2 - 3 } & Std. Deviation & 1.63161905 \\
\hline \multirow{2}{*}{ Most Extreme Differences } & Absolute & .118 \\
\cline { 2 - 3 } & Positive & .118 \\
\cline { 2 - 3 } & Negative & -.116 \\
\hline Test Statistic & & .118 \\
\hline Asymp. Sig. (2-tailed) & & .203 \\
\hline
\end{tabular}

Based on table 3 , the normality value is 0.203 . Because this number is more than 0.05 , the data may be assumed to be normally distributed. Furthermore, the homogeneity test is the second necessary exam. A homogeneity test was done to determine whether or not the study data employed was homogenous. Table 4 shows the results of the homogeneity test.

Table 4. Homogeneity test results

Test of Homogeneity of Variances

\begin{tabular}{ll|l|l|l|l} 
& Levene Statistic & df1 & df2 & Sig. \\
\hline \multirow{2}{*}{ Pretest } & Based on Mean & 2.175 & 1 & 58 & .146 \\
\cline { 2 - 6 } & Based on Median & 3.467 & 1 & 58 & .068 \\
\cline { 2 - 5 } & $\begin{array}{l}\text { Based on Median and with } \\
\text { adjusted df }\end{array}$ & 3.467 & 1 & 56.320 & .068 \\
& & & & \\
\hline Based on trimmed mean & 2.609 & 1 & 58 & .112 \\
\hline
\end{tabular}

Table 4 demonstrates that the data homogeneity of communication skills of SMP Negeri 46 Kerinci students has a significant value of 1.48 larger than 0.05. The data is homogeneously distributed, based on the information presented above. A t-test using an Independent sample t-test was also used to examine the influence of the scientific approach on students' communication skills in social studies learning. Table 5 summarizes the findings of the $t$ test.

Table 5. t-test results

Independent Samples Test

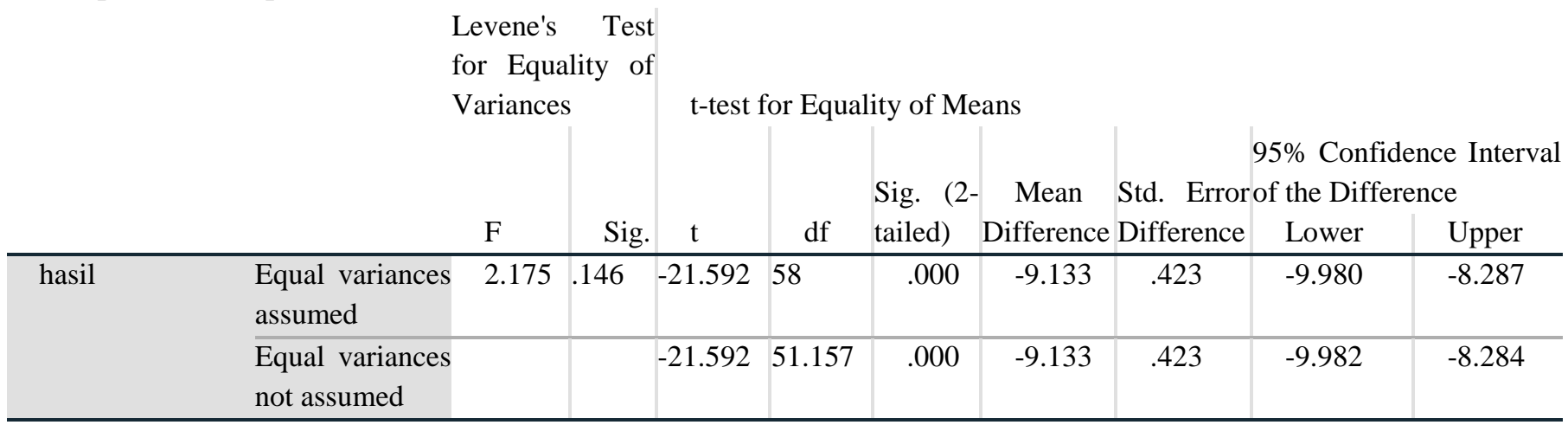

The t-test was used to determine the influence of the scientific approach on students' communication skills in social studies learning, as shown in Table 5. The significance value ( $\mathrm{Sig}$ ) of the test findings is 0.000 (less than 0.05), indicating that applying the scientific approach in social studies instruction has a substantial impact on the communication skills of 46 Kerinci Junior High School pupils. 


\section{International Journal of Current Science Research and Review}

ISSN: 2581-8341

Volume 04 Issue 12 December 2021

DOI: 10.47191/ijesrr/V4-i12-14, Impact Factor: 5.825

IJCSRR@ 2021

Www.ijesrr.org

\section{DISCUSION}

The findings suggest that utilizing a scientific approach in social studies instruction has a considerable impact on students' communication skills. The difference in the average score of the pretest and posttest tests confirms this. A t-test significance value of 0.000 or less than 0.05 is also indicative. As a conclusion, it was discovered that using a scientific approach to studying social studies had a considerable positive impact on boosting students' communication skills. The outcomes of this study support the previous findings (Saputra \& Prasetyono, 2020; Indrilla, 2018; Utami \& Murti, 2018) showing the scientific approach can increase higher-order thinking skills and boost social skills including teamwork, problem solving, and communication.

When compared to students who learn with a teacher-centered (traditional) approach, students who study with a scientific approach have superior success in solving problems. Students may develop their own knowledge with the help of the scientific approach, resulting in strong teamwork, communication, and critical thinking skills (Zainudin \& Istiyono, 2019). Students are taught to develop higher order thinking skills in every learning process using a scientific approach that includes five steps: observing, asking, investigating, analyzing, and communicating. When compared to the employment of traditional teacher-centered techniques in the teaching and learning process, each level of the scientific approach allows students to be actively involved in the learning process. This is due to the scientific approach's characteristics, which include student-centered learning, highlights the process of acquiring knowledge, incorporates prospective cognitive capabilities in encouraging intellectual development, and stresses student character in problem-solving (Estuhono \& Mahmudi, 2021).

Communication skills as the final part of the scientific approach is the stage where pupils communicate the results of the analysis of the completion of a topic/problem, either personally, in writing, or through other media. This communication ability is critical for kids since it will make it simpler for them to take information on a variety of issues. Communication promotes a learning experience by presenting the findings from data collected and conclusions reached based on analysis. This is to provide students the chance to strengthen their critical thinking skills, as well as their capacity to think systematically, communicate concepts clearly and concisely, and talk effectively and accurately. Based on the discussion above, it can be stated that using a scientific approach to learning can help students enhance their higher order thinking skills, such as teamwork, problem solving, and communication.

\section{CONCLUSION}

Using a scientific approach to studying social studies has a positive impact on boosting students' communication skills. Students are taught to develop higher order thinking skills in every learning process using the scientific approach that includes five steps: observing, asking, investigating, analyzing, and communicating. The scientific approach's characteristics include student-centered learning, highlights the process of acquiring knowledge, incorporates prospective cognitive capabilities, and stresses student character in problem-solving.

\section{REFERENCE}

1. Ariawan, I. M. E., Darsana, I. W., \& Suardika, I. W. R. (2015). The effect of the scientific approach on learning outcomes of mathematics knowledge on the theme of my ideals in terms of the characteristics of the teacher's questions to fourth grade students of SD Negeri 27 pemecutan. MIMBAR PGSD Undiksha, 3(1).

2. Chasanah, C. (2020). The Effectiveness of Learning Models on Written Mathematical Communication Skills Viewed from Students' Cognitive Styles. European Journal of Educational Research, 9(3), 979-994.

3. Estuhono, E., \& Mahmudi, M. R. (2021). Development of a Science Model Based on a Research-Based Learning Model to Develop Four Cs Skills on the Environmental Theme of Our Friends at 210 Tanjung Dani Elementary School. Consilium: Education and Counseling Journal, 1(2), 232-243.

4. Hansen, E. J., \& Stephens, J. A. (2000). The ethics of learner-centered education: Dynamics that impede the process. Change: The Magazine of Higher Learning, 32(5), 40-47.

5. Hernawati, D., Amin, M., Irawati, M. H., Indriwati, S. E., \& Omar, N. (2018). The effectiveness of scientific approach using encyclopedia as learning materials in improving students' science process skills in science. Jurnal Pendidikan IPA Indonesia, 7(3), 266-272. 


\section{International Journal of Current Science Research and Review}

ISSN: 2581-8341

Volume 04 Issue 12 December 2021

DOI: 10.47191/ijcsrr/V4-i12-14, Impact Factor: 5.825

IJCSRR@ 2021

WWw.ijesrr.org

6. Indrilla, N. (2018). The effectiveness of scientific approach and contextual teaching and learning approach in teaching writing. Lingua Cultura, 12(4), 405-413.

7. Indriyani, I. E., Syaharuddin, S., \& Jumriani, J. (2021). Social Interaction Contents on Social Studies Learning to Improve Social Skills. The Innovation of Social Studies Journal, 2(2), 93-102.

8. Jungst, S. E., Licklider, B. L., \& Wiersema, J. A. (2003). Provoding Support for Faculty Who Wish to Shift to a LearningCentered Paradigm in Their Higher Education Classrooms. Journal of Scholarship of Teaching and Learning (JoSoTL).

9. Machemer, P. L., \& Crawford, P. (2007). Student perceptions of active learning in a large cross-disciplinary classroom. Active learning in higher education, 8(1), 9-30.

10. Marbach-Ad, G., Seal, O., \& Sokolove, P. (2001). Student Attitudes and Recommendations on Active Learning. Journal of College Science Teaching.

11. Mertens, D. M. (2019). Research and evaluation in education and psychology: Integrating diversity with quantitative, qualitative, and mixed methods. Sage publications.

12. Moust, J. H., Berkel, H. V., \& Schmidt, H. G. (2005). Signs of erosion: Reflections on three decades of problem-based learning at Maastricht University. Higher education, 50(4), 665-683.

13. Permanawati, F. I., Agoestanto, A., \& Kurniasih, A. W. (2018). The students' critical thinking ability through problem posing learning model viewed from the students' curiosity. Unnes Journal of Mathematics Education, 7(3), 147-155.

14. Saputra, S., \& Prasetyono, H. (2020). The Effect of Scientific Approach to the Activity of Learning Students in SMPN 25 Tangerang City. Jurnal PAJAR (Pendidikan Dan Pengajaran), 4(1), 20-30.

15. Setiawan, D. (2017). Authentic Assessment Model in Social Studies Learning To Improve the Social Skills. Turkish Online J. Des. Art Commun, 7, 1393-1403.

16. Syarifuddin, S. (2018). The effect of using the scientific approach through concept understanding and critical thinking in science. Jurnal Prima Edukasia, 6(1), 21-31.

17. Tambunan, H. (2019). The Effectiveness of the Problem Solving Strategy and the Scientific Approach to Students' Mathematical Capabilities in High Order Thinking Skills. International Electronic Journal of Mathematics Education, 14(2), 293-302.

18. Untayana, J. R., \& Harta, I. (2016). Development of limit learning tools based on scientific approach-oriented learning achievement and mathematical communication skills. Jurnal Riset Pendidikan Matematika, 3(1), 45-54.

19. Utami, A. U., \& Murti, S. C. C. (2018). The effectiveness of scientific approach-based science learning materials to educate students science literacy. JPPS (Jurnal Penelitian Pendidikan Sains), 8(1).

20. Wibowo, A. (2017). The effect of realistic and scientific mathematics learning approaches on learning achievement, mathematical reasoning ability and interest in learning. Jurnal Riset Pendidikan Matematika, 4(1), 1-10.

21. Yafie, E., Nirmala, B., Kurniawaty, L., Bakri, T. S. M., Hani, A. B., \& Setyaningsih, D. (2020). Supporting cognitive development through multimedia learning and scientific approach: An experimental study in preschool. Universal Journal of Educational Research, 8(11C), 113-123.

22. Zahabioun, S., Yousefy, A., Yarmohammadian, M. H., \& Keshtiaray, N. (2013). Global citizenship education and its implications for curriculum goals at the age of globalization. International Education Studies, 6(1), 195-206.

23. Zainudin, M., \& Istiyono, E. (2019). Scientific Approach to Promote Response Fluency Viewed from Social Intelligence: Is It Effective? European Journal of Educational Research, 8(3), 801-808.

Cite this Article: Ismail Buhari, Tri Zahra Ningsih (2021). Improving Student's Communication Skills in Social Science Learning Through a Scientific Approach. International Journal of Current Science Research and Review, 4(12), 1704-1709 